\title{
Tufted Hairgrass Responses to Heat and Drought Stress
}

\author{
Eric Watkins ${ }^{1}$, Bingru Huang, and William A. Meyer \\ Department of Plant Biology and Pathology, Rutgers University, 59 Dudley Road, New Brunswick, \\ NJ 08901
}

\begin{abstract}
AdDitional IndeX words. Deschampsia cespitosa, turfgrass breeding, low-maintenance
Abstract. Tufted hairgrass [Deschampsia cespitosa (L.) Beauv.] is receiving increasing attention as a low-maintenance turfgrass for use in areas with reduced fertility or reduced sunlight. The objectives of this study were to examine physiological responses of tufted hairgrass to heat and drought stress and to distinguish whether better summer performance was related to better heat or drought tolerance. Four germplasm lines were chosen based on summer performance in field plots (two lines resistant to summer stress and two lines susceptible to summer stress) and were grown in growth chambers [14-hour photoperiod, $20 / 15{ }^{\circ} \mathrm{C}$ (day/night)]. Plants were exposed to either drought stress or heat stress $\left(35 / 30{ }^{\circ} \mathrm{C}\right.$, day/night) for up to 49 days. Control plants maintained under normal conditions $\left(20 / 15{ }^{\circ} \mathrm{C}\right.$, day/night, well watered) were included for both treatments. During the course of the study, single-leaf photosynthetic rate, photochemical efficiency, and relative water content were measured, and turf quality was visually rated. All parameters for all tufted hairgrass lines decreased under drought stress and heat stress, and the decline was more severe for summer stress-susceptible lines than for resistant lines. Lines that were previously considered resistant to summer stress exhibited superior photochemical efficiency under heat stress compared with the susceptible lines. When subjected to drought stress, the lines exhibited little or no differences in the measured parameters. These results suggest that observed variation in field summer performance among various tufted hairgrass germplasm lines may be mainly the result of their differences in heat tolerance. These results suggest that selecting for heat-tolerant germplasm could be important for further improvement in turf performance of tufted hairgrass during the summer.
\end{abstract}

Tufted hairgrass is a cool-season bunch grass adapted to cool climatic regions and environments that have adequate soil moisture (Davy, 1980; Hagerup, 1939). Recently, turfgrass breeders in the United States and Europe have initiated research on this species for use as a turfgrass (Brilman et al., 2000; Crossley et al., 2001; Morris, 2002; Watkins and Meyer, 2005). The species has performed adequately under conditions of reduced fertilizer inputs and can be used in shaded conditions (Brilman and Watkins, 2003). Tufted hairgrass performs well as a turfgrass during the spring; however, the species does not perform adequately during the summer in warm climates. Overall turfgrass quality of tufted hairgrass declines rapidly beginning in late June in New Jersey (pers. obs.) and continues to decline throughout the rest of the summer months. This susceptibility to summer stress prevents tufted hairgrass from being widely used as a turfgrass in the United States. Currently available cultivars of this species do not compare well in terms of overall, long-term turfgrass quality with other cool-season species commonly used in low-maintenance situations (Han et al., 2002).

Many factors may contribute to tufted hairgrass summer decline, including heat stress (HT) and drought stress (DS). Because this species is often found in nature growing in wetland habitats and areas that do not have high summer temperatures (Davy, 1980; Hagerup, 1939), tufted hairgrass may be sensitive to DS and HT. The detrimental effects of HT and DS are well-known in other cool-season turfgrass species, including

Received for publication 9 Aug. 2006. Accepted for publication 29 Jan. 2007. Manuscript was submitted by the senior author in partial fulfillment of the requirement for a doctoral degree from Rutgers University.

${ }^{1}$ Corresponding author. Current address: University of Minnesota, Horticultural Science, 305 Alderman Hall, 1970 Folwell Avenue, St. Paul, MN 55108.

E-mail: ewatkins@umn.edu. kentucky bluegrass (Poa pratensis L.) (Ervin and Koski, 1998; Jiang and Huang, 2000), perennial ryegrass (Lolium perenne L.) (Jiang and Huang, 2001; Minner et al., 1983; Wehner and Watschke, 1981), creeping bentgrass (Agrostis stolonifera L.) (Liu and Huang, 2000; Xu and Huang, 2001a), and tall fescue (Festuca arundinacea Schreb.) (Huang et al., 1998; Qian et al., 1997). However, the relative sensitivity or tolerance to DS or HT for tufted hairgrass is unknown. In Europe, tufted hairgrass is typically not found in areas with mean June temperatures higher than $20^{\circ} \mathrm{C}$, and species distribution does not appear to be related to rainfall differences, although it will not grow in arid regions with severe drought (Davy, 1980). When compared with tall fescue, tufted hairgrass seedlings were shown to have lower photochemical efficiency at high temperatures (Steiner et al., 2001).

Information about HT and DS tolerance in tufted hairgrass is important for germplasm improvement. Tufted hairgrass germplasm lines vary in their response to summer stress. It is difficult to distinguish between the effects of HT and DS in the field. The primary objective of this study was to evaluate the effect of DS and HT on tufted hairgrass. A secondary purpose of this study was to compare lines with varying field responses to summer stress to determine whether DS or HT had a greater contribution to observed differences in summer performance. Identifying factors associated with improved summer stress resistance in this species will aid in the development of superior tufted hairgrass germplasm.

\section{Materials and Methods}

Germplasm used in this study consisted of tufted hairgrass lines originating from Norway. In 1999, individual tufted 
hairgrass plants were collected from various sites in Norway. After the collection trip, each collected plant was taken to a breeding farm in Holland, where it was divided into five propagules. The propagules from a single collection were planted in a single row. The various rows representing all the collected material were planted in the same breeding nursery; therefore, cross-pollination occurred between individual collections [the species does not readily self-pollinate (Davy, 1980)]. Seed (progeny) from the five propagules was bulked; these progeny will hereafter be collectively referred to as a "germplasm line" or "line." All progeny in the same germplasm line are considered to be half-sibs. Seed was harvested and sent to New Jersey, and seed from individual lines was used to establish a single turf plot.

In the current study, four germplasm lines were chosen based on summer turf performance in field plots in a low-input turf trial (no fertilization, irrigation, or other inputs after establishment) in Pittstown, N.J. (Watkins and Meyer, 2005). Two of the lines were classified as resistant to summer stress (14378 and 14550, hereafter referred to as R1 and R2 respectively) and two were classified as susceptible to summer stress (14492 and 14568, hereafter referred to as S1 and S2 respectively) based on differences in visual turf quality during summer. The four lines originated from various collection sites in Norway (R1 from a natural area on Hitra Island, R2 from a cemetery in Krekling, S1 from a city park in Bergen, S2 from a golf course in Oslo). The lines performed similarly in terms of overall turfgrass quality before the onset of summer stress. Turf quality ratings (measured using a 9-point scale, where 9 points is best turfgrass quality) were 4.0, 5.0, 6.0, and 6.0 for lines R1, $\mathrm{R} 2, \mathrm{~S} 1$, and S2 respectively, before summer stress (average of two rating dates in May). The average turf quality of those lines was 5.0, 5.0, 2.0, and 1.0 respectively, following summer stress (average of two rating dates during Sept.).

In Apr. 2002, sods (10 cm in diameter and $\approx 2 \mathrm{~cm}$ thick) of tufted hairgrass were collected from field plots at the Rutgers Plant Biology and Pathology Research and Extension Station at Adelphia, N.J. These plots were established with seed from individual germplasm lines in Aug. 2001 (Han et al., 2003). Therefore, plants used in the current study had not experienced any summer stress in the field. Sods were washed free of soil and then planted in plastic containers $(22-\mathrm{cm}$ depth and $20-\mathrm{cm}$ diameter for HT plants or 30-cm depth and $18-\mathrm{cm}$ diameter for DS plants) filled with a mixture of sand and soil (fine-loamy, mixed, mesic Typic Hapludult; 1 sand:10 soil, by volume). Plants were watered as needed and clipped weekly to a height of $12 \mathrm{~cm}$. Plants were maintained in a greenhouse for $60 \mathrm{~d}(12-\mathrm{h}$ photoperiod, $\approx 20^{\circ} \mathrm{C}$ ).

The plants were then transferred to growth chambers with a temperature of $20 / 15^{\circ} \mathrm{C}$ (day/night), photosynthetically active radiation of $600 \mu \mathrm{mol} \cdot \mathrm{m}^{-2} \cdot \mathrm{s}^{-1}$, and a $14-\mathrm{h}$ photoperiod. Growth chamber conditions were consistent throughout the course of the experiment. The plants were maintained in growth chambers for $50 \mathrm{~d}$ before the treatments began, which allowed sufficient recovery from any problems associated with transfer from the field. Plants were fertilized twice with controlledrelease fertilizer containing $19.5 \mathrm{~g} \cdot \mathrm{m}^{-2} \mathrm{~N}(16 \mathrm{~N}-1.8 \mathrm{P}-6.7 \mathrm{~K})$ before being exposed to stresses. Before the beginning of the treatments, plants were clipped weekly to a height of $12 \mathrm{~cm}$.

The DS experiment included two soil moisture treatments: well watered (control) and no water (DS). Drought stress was induced by withholding irrigation. Control plants were watered every other day throughout the experiment. All physiological measurements were taken just before the treatment began and once per week thereafter. The drought experiment lasted until physiological measurements could no longer be made because of the lack of green tissue on stressed plants (35 d). Throughout the DS experiment, visual ratings were taken using a 9-point scale (where 9 points is best) for turfgrass quality. Drought stress ratings were evaluated based on the amount of green tissue remaining (where 1 point is no green tissue remaining and 9 points is all green tissue).

Single-leaf photosynthetic rate $\left(\mathrm{P}_{\mathrm{n}}\right)$ of three individual leaves was measured twice per plant with a LI-6400 portable gas exchange system (LI-COR, Lincoln, Nebr.) and were expressed as micromoles of $\mathrm{CO}_{2}$ uptake per unit leaf area (per square meter per second). Leaf photochemical efficiency was expressed as chlorophyll fluorescence (FV-to-Fm ratio) and was determined on two randomly selected leaves in each container using a fluorescence induction monitor (FIM 1500; ADC BioScientific Ltd., Hoddesdon, UK). Relative water content (RWC) of leaves was determined four times throughout the course of the DS study. Leaf RWC was calculated after taking leaf fresh weight (FW), then soaking the leaves in deionized water for $24 \mathrm{~h}$ to obtain turgid weight (TW), and finally drying the leaves in an oven at $75^{\circ} \mathrm{C}$ to determine dry weight $(\mathrm{DW})[\mathrm{RWC}=(\mathrm{FW}-\mathrm{DW}) /(\mathrm{TW}-\mathrm{DW})]$.

Soil water content was monitored with time domain reflectometry each time physiological measurements were taken using $20-\mathrm{cm}$ soil probes installed vertically into the soil profile (6050X1 Trase System; Soilmoisture Equipment Corp., Santa Barbara, Calif.).

The heat experiment included two temperature treatments: control $\left(20 / 15^{\circ} \mathrm{C}\right.$, day/night) and HT $\left(35 / 30{ }^{\circ} \mathrm{C}\right.$, day/night). Plants in the HT experiment were watered regularly so that plants did not experience moisture stress. The same physiological measurements made in the DS experiment were made during HT treatment; however, measurements were made at different intervals: before onset of high-temperature treatment, 1 week after initiation of treatment, and every other week thereafter. The HT experiment lasted for $49 \mathrm{~d}$.

Each treatment (DS and HT) included all four germplasm lines and was arranged in a randomized complete block design and replicated in four growth chambers. Each growth chamber was considered a block and contained one replication of each treatment. Each replication consisted of one pot each of all four lines along with a corresponding control plant for each line; therefore, one replication in one treatment consisted of eight pots of plants (control plants for HT were maintained in four separate growth chambers). All data were subjected to analysis of variance according to the general linear model procedure of SAS (SAS Institute, Cary, N.C.). Treatment means and germplasm line means (within treatment) were separated by Tukey's mean separation at $P \leq 0.05$. For single-leaf photosynthesis data, lines were pooled because of similarity, and only treatment means are presented (Fig. 1).

\section{Results}

When subjected to either DS or HT, turfgrass quality of all lines declined steadily during the course of the experiment. The average turfgrass quality of DS plants fell below an acceptable level (6.0 points) at $7 \mathrm{~d}$ of stress (Fig. 2). Turfgrass quality of HT plants became significantly lower than the control starting 

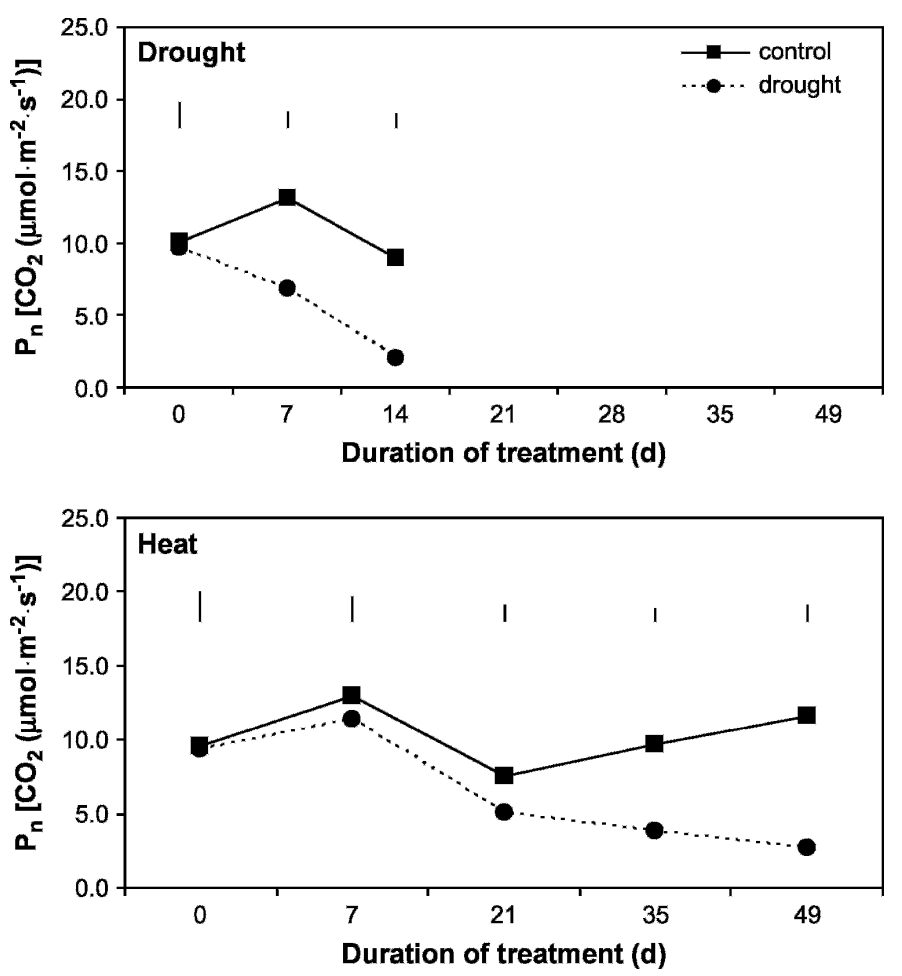

Fig. 1. Net photosynthesis $\left[\mathrm{P}_{\mathrm{n}}\right.$ (measured in micromoles of $\mathrm{CO}_{2}$ uptake per square meter per second)] of tufted hairgrass plants as affected by drought or heat stress (pooled results of four germplasm lines). Vertical bars indicate minimum significant difference (Tukey's mean separation, $P \leq 0.05$ ) for treatment comparisons (stress vs. control) under stress. All lines were averaged for each treatment.

at $21 \mathrm{~d}$ (control, 6.5 points; HT, 5.3 points) and the decline was more pronounced with increasing stress duration $(35 \mathrm{~d}, 5.7$ points; 49 d, 4.4 points; Fig. 2). Line S2 performed significantly below the other lines at $49 \mathrm{~d}$ of HT (Fig. 2). Turfgrass quality ratings declined more dramatically under DS than under HT. After $21 \mathrm{~d}$, turf quality of DS plants was 54\% below that of control plants; after the same period of the HT study, HT plants had turfgrass quality ratings $18 \%$ below control plants (Fig. 2).

Green tissue ratings for DS plants declined steadily beginning at $7 \mathrm{~d}$ (Fig. 3). At $35 \mathrm{~d}$, there was an absence of green tissue for all DS plants (data not shown). Green tissue ratings for HT plants declined throughout the study; however, HT plants maintained some green tissue throughout the course of the experiment (Fig. 3). As with turf quality ratings, green tissue ratings declined more severely under DS than HT. During HT, both turfgrass quality and green tissue ratings showed intraspecific differences.

There were no significant differences in $\mathrm{P}_{\mathrm{n}}$ among the different germplasm lines; therefore, data were averaged to compare treatment effects (Fig. 1). Single-leaf $\mathrm{P}_{\mathrm{n}}$ declined by $29.8 \%$ within $7 \mathrm{~d}$ of DS (Fig. 1). At $14 \mathrm{~d}, \mathrm{P}_{\mathrm{n}}$ declined to almost zero and measurements were no longer taken. Beginning at $21 \mathrm{~d}$ of HT, $\mathrm{P}_{\mathrm{n}}$ levels dropped below that of control plants (Fig. 1). The difference between the control and HT plants was the greatest at $35 \mathrm{~d}\left(9.7 \mu \mathrm{mol} \cdot \mathrm{m}^{-2} \cdot \mathrm{s}^{-1} \mathrm{CO}_{2}\right.$ and $3.8 \mu \mathrm{mol} \cdot \mathrm{m}^{-2} \cdot \mathrm{s}^{-1}$ $\mathrm{CO}_{2}$ respectively) and $49 \mathrm{~d}\left(11.6 \mu \mathrm{mol} \cdot \mathrm{m}^{-2} \cdot \mathrm{s}^{-1} \quad \mathrm{CO}_{2}\right.$ and $2.7 \mu \mathrm{mol} \cdot \mathrm{m}^{-2} \cdot \mathrm{s}^{-1} \mathrm{CO}_{2}$ respectively).

Leaf photochemical efficiency, expressed as an Fv-to-Fm ratio, declined to below the level of the control at $21 \mathrm{~d}$ of DS (Fig. 4). Pronounced differences in photochemical efficiency
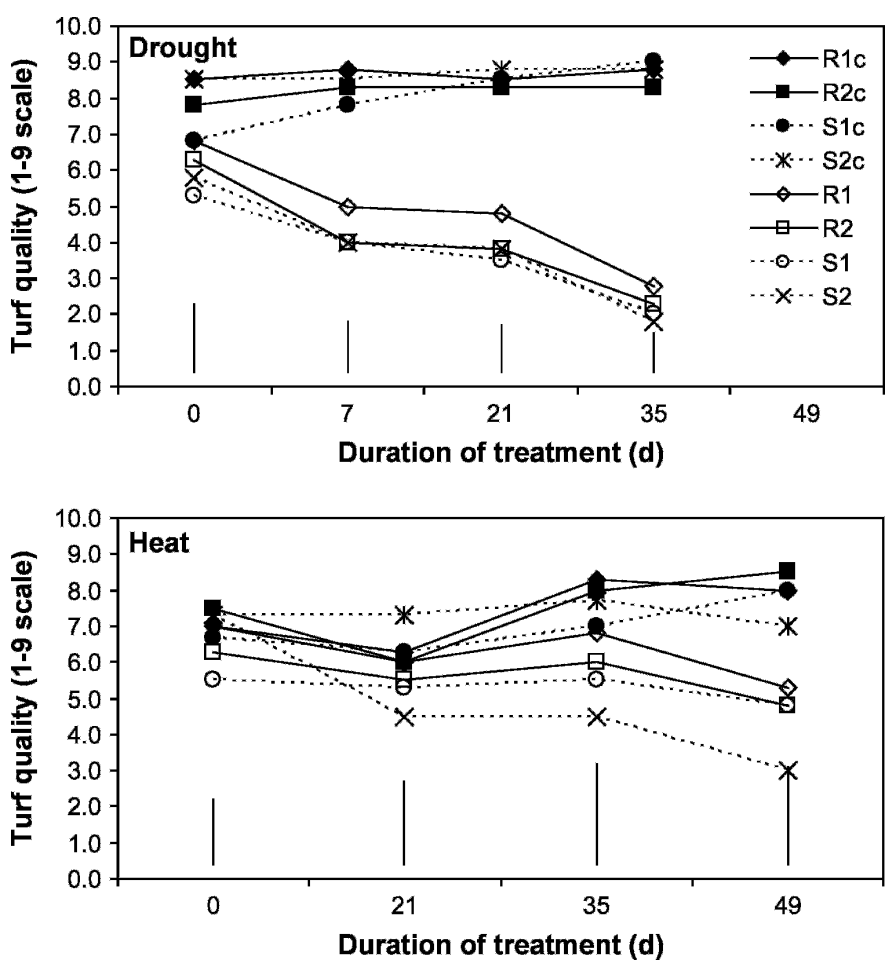

Fig. 2. Turf quality (measured using a 9-point scale, where 9 points is best turfgrass quality) of four tufted hairgrass germplasm lines as affected by drought or heat stress. Control lines are followed by a "c" in the legend. Vertical bars indicate minimum significant difference (Tukey's mean separation, $P \leq 0.05$ ) for germplasm line comparisons under stress.

between the control and HT plants were not observed until $35 \mathrm{~d}$ and $49 \mathrm{~d}$ respectively (Fig. 4). At $21 \mathrm{~d}$ of stress, photochemical efficiency of DS plants was $79 \%$ of control whereas photochemical efficiency of HT plants was $96 \%$ of control. Differences in photochemical efficiency between germplasm lines under HT were significant at $49 \mathrm{~d}$, with $\mathrm{S} 1$ and S2 having the lowest Fv-to-Fm ratio. These differences were not detected during DS.

Relative water content of DS plants declined rapidly below the control level for all lines. Relative water content of HT plants did not decrease significantly below the level of the control until 49 d (Fig. 5), whereas RWC of DS plants declined significantly below the control at $14 \mathrm{~d}$ (Fig. 5). Intraspecific differences were detected for RWC during the HT (Fig. 5), but not during DS (Fig. 5). At $35 \mathrm{~d}$ of HT, R2 had the highest RWC (82\%) whereas S2 had the lowest RWC (70\%).

Soil moisture levels of control and HT plants remained fairly constant $(\approx 30 \% \mathrm{v} / \mathrm{v})$, whereas those of DS plants declined throughout the experiment. On average, the initial level was $25 \%$ and dropped to $8 \%$ by $21 \mathrm{~d}$ of DS.

\section{Discussion}

Turf quality declined with DS and HT for all germplasm lines of tufted hairgrass. All physiological parameters examined $\left(\mathrm{P}_{\mathrm{n}}, \mathrm{F}_{\mathrm{v}} / \mathrm{F}_{\mathrm{m}}\right.$, and RWC) maintained higher levels for a longer duration under HT $\left(35^{\circ} \mathrm{C}\right)$ than under DS, suggesting that tufted hairgrass was more sensitive to DS than to HT. Jiang and Huang (2000) reported that a decline in canopy $P_{n}$ for kentucky bluegrass was more severe under HT than under 

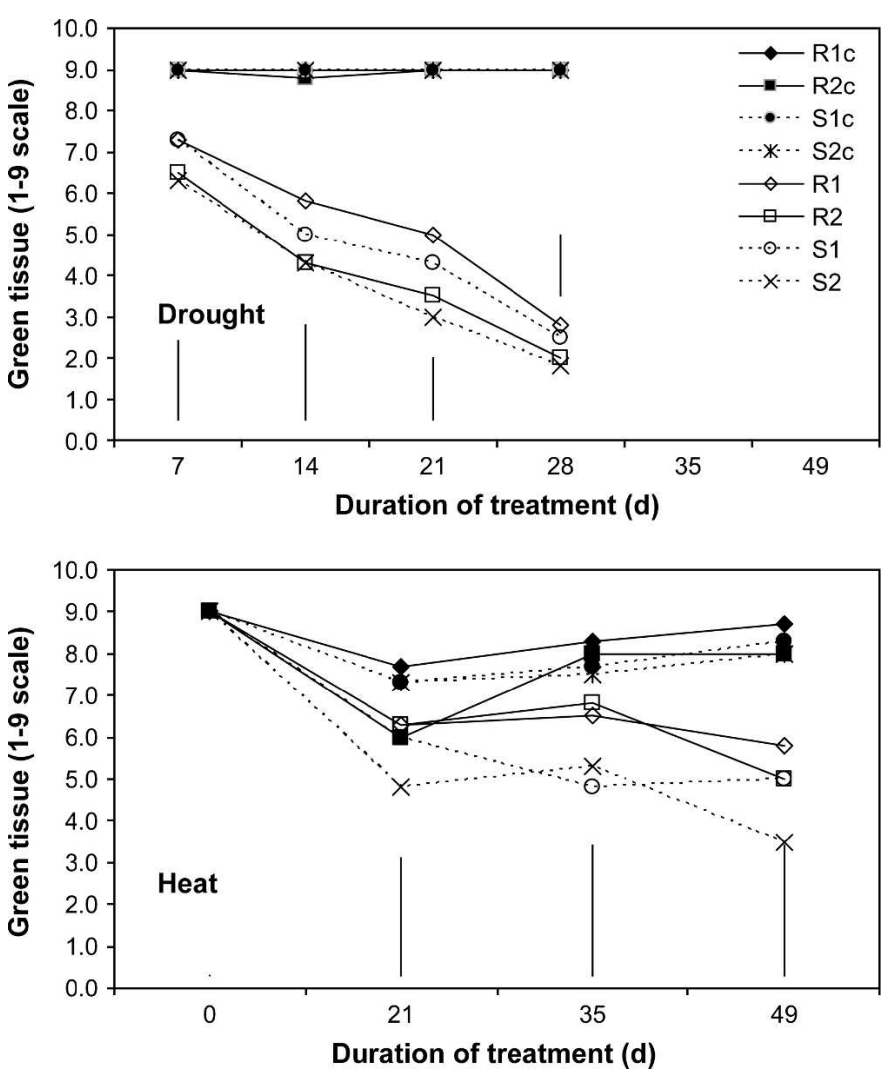

Fig. 3. Green tissue ratings (measured using a 9-point scale, where 9 points is all green tissue) of four tufted hairgrass germplasm lines as affected by drought or heat stress. Control lines are followed by a " $c$ " in the legend. Vertical bars indicate minimum significant difference (Tukey's mean separation, $P \leq 0.05$ ) for germplasm line comparisons under stress.

DS during the first $12 \mathrm{~d}$ of treatment; however, the reduction in the Fv-to-Fm ratio was more severe under DS than HT after $20 \mathrm{~d}$ of treatment.

Decline under HT and DS was associated with decreases in $\mathrm{P}_{\mathrm{n}}, \mathrm{F}_{\mathrm{v}} / \mathrm{F}_{\mathrm{m}}$, and RWC. These results are similar to those found for other cool-season turfgrass species (Huang and Fu, 2001; Huang et al., 1998; Jiang and Huang, 2000; Xu and Huang, 2001b). The ability to maintain photosynthesis and photochemical efficiency during HT is likely an important factor in heat-tolerant tufted hairgrass plants. Howard and Watschke (1991) found that kentucky bluegrass cultivars that were tolerant of HT exhibited high net photosynthetic rates, and suggested that heat-tolerant cultivars had a greater capacity for photosynthetic electron transport than did the heat-intolerant cultivars. Selecting germplasm that can maintain higher photosynthesis and photochemical efficiency under stress conditions should lead to cultivars with improved summer stress tolerance (Jiang and Huang, 2001).

In addition to photosynthetic parameters, other factors may also play important roles in heat tolerance. In creeping bentgrass, cultivar differences in heat tolerance were shown to be associated with variations in antioxidant enzyme activities (Liu and Huang, 2000). Park et al. (1997) showed that after heat shock (and expression of various heat-shock proteins), heattolerant creeping bentgrass plants were able to resume normal protein synthesis earlier than the nontolerant plants. To select properly for heat-tolerant cultivars in a breeding program, a focus on morphological characteristics may also be advanta-
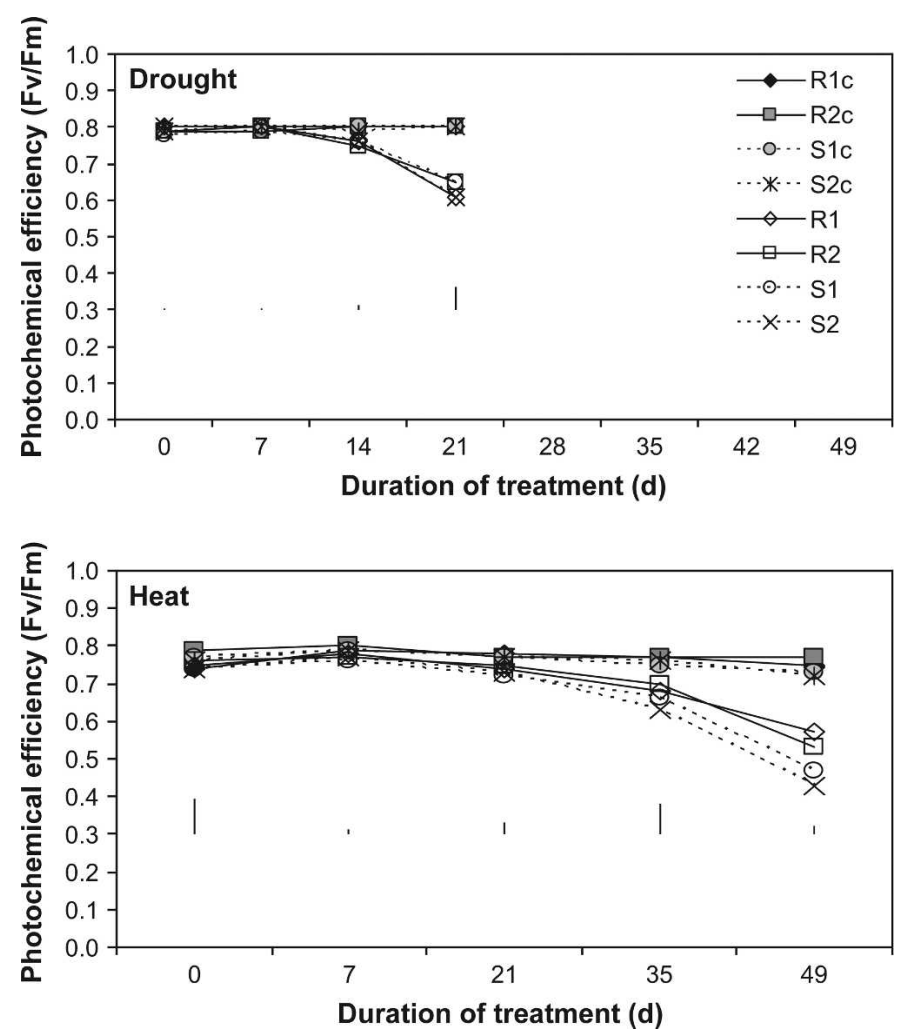

Fig. 4. Photochemical efficiency, expressed as $\mathrm{Fv} / \mathrm{Fm}$, of four tufted hairgrass germplasm lines as affected by drought or heat stress. Control lines are followed by a "c" in the legend. Vertical bars indicate minimum significant difference (Tukey's mean separation, $P \leq 0.05$ ) for germplasm line comparisons under stress.

geous. Xu and Huang (2001b) found that the creeping bentgrass cultivar L-93 performed better under HT because of morphological characteristics such as narrow leaves, dense tillers, and a large root system. Narrow leaves and dense tillers are advantageous for increased transpirational cooling under nonlimiting soil moisture conditions. Variability for high-temperature and DS tolerances has also been found in other turfgrass species: kentucky bluegrass (Bonos and Murphy, 1999; Howard and Watschke, 1991), tall fescue (Huang and Gao, 1999; Huang et al., 1998), and perennial ryegrass (Minner et al., 1983).

The current study found that declines in all physiological measurements began $7 \mathrm{~d}$ after the onset of DS for all tufted hairgrass lines, and no significant differences among those lines were detected for any parameter. Huang et al. (1998) showed that a less-drought-tolerant tall fescue cultivar had a more severe reduction in RWC and chlorophyll fluorescence than a cultivar with better drought tolerance. Huang and Gao (1999) found variation for drought resistance among six tall fescue cultivars; the primary physiological differences between susceptible and resistant cultivars were in photosynthetic capacity and water relations. Turfgrass cultivars that differ in growth habit have been shown to have different responses to DS (Huang and Gao, 1999; Huang et al., 1998). In our study, shoot differences in drought responses among different germplasm lines were not apparent; however, differences in soil moisture extraction at deeper depths could account for summer performance differences. Root distribution variability has been used as a selection criterion for drought-tolerant tall 

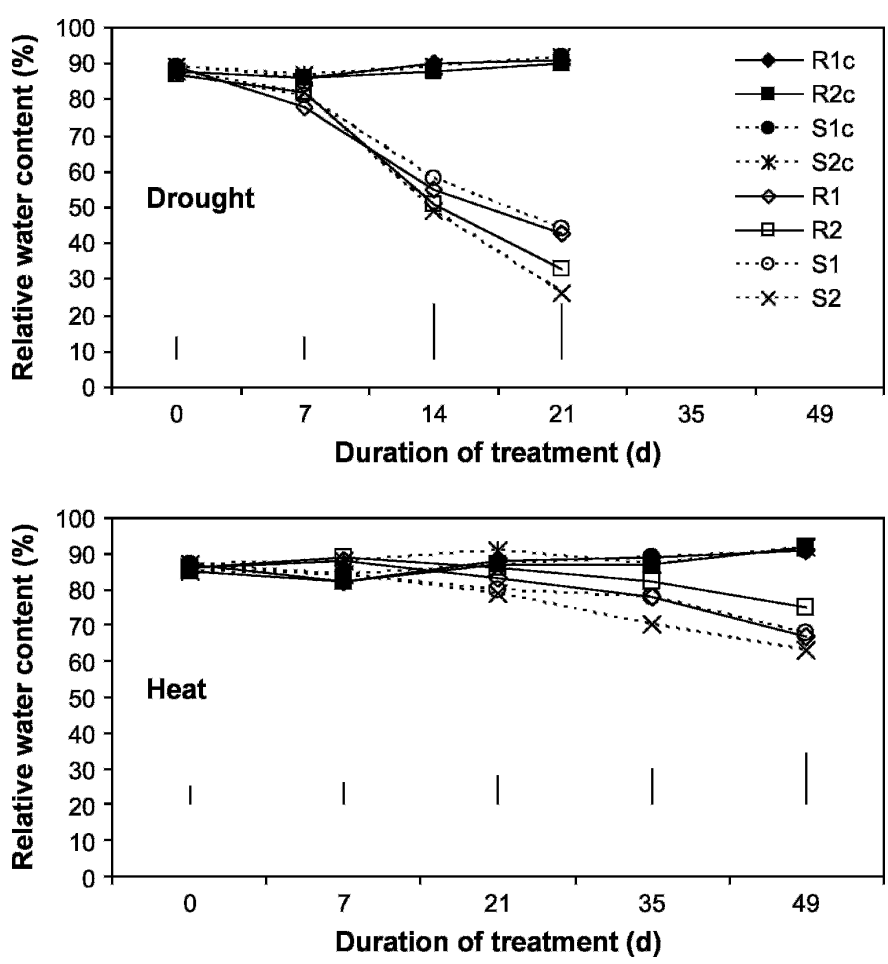

Fig. 5. Relative water content of four tufted hairgrass germplasm lines as affected by drought or heat stress. Control lines are followed by a "c" in the legend. Vertical bars indicate minimum significant difference (Tukey's mean separation, $P \leq 0.05$ ) for germplasm line differences under stress.

fescue (Ervin and Koski, 1998) and creeping bentgrass (Salaiz et al., 1991) germplasm. Further investigation of tufted hairgrass DS tolerance under field conditions in replicated trials is needed.

Significant differences in heat tolerance were detected among germplasm lines; however, this study did not detect differences in DS tolerance between tufted hairgrass germplasm lines. In the HT study, the poorest performing line (S2) was previously observed to be susceptible to summer stress under field conditions, whereas the top performing line (R1) was previously observed to be resistant to summer stress. These results suggest that tolerance to HT may play a more important role in summer performance differences for tufted hairgrass. Plant breeders may be able to make significant gains in summer stress tolerance by screening tufted hairgrass germplasm for HT tolerance.

\section{Literature Cited}

Bonos, S.A. and J.A. Murphy. 1999. Growth responses and performance of kentucky bluegrass under summer stress. Crop Sci. 39: 770-774.

Brilman, L. and E. Watkins. 2003. Hairgrasses, p. 225-231. In: M.D. Casler and R.R. Duncan (eds.). Turfgrass biology, genetics, and breeding. Wiley, New York.

Brilman, L.A., E. Watkins, and W.A. Meyer. 2000. Tufted hairgrass: A new turfgrass species. Golf Course Mgt. 68:56-60.

Crossley, F.M.E., A.J. Newell, R. Carrington, J.L. Pratt, A.D. Riding, J.C. Hart-Woods, and A.D. Wood. 2001. Sports Turf Research
Institute report to turfgrass breeders 2001. Sports Turf Research Institute, Bingley, UK.

Davy, A.J. 1980. Biological flora of the British Isles: Deschampsia caepitosa (L.). Beauv. J. Ecol. 68:1075-1096.

Ervin, E.H. and A.J. Koski. 1998. Drought avoidance aspects and crop coefficients of kentucky bluegrass and tall fescue turfs in the semiarid west. Crop Sci. 38:788-795.

Hagerup, O. 1939. Studies on the significance of polyploidy. Hereditas 25:185-193.

Han, Y., P. Perdomo, J.A. Murphy, W.A. Meyer, S.A. Bonos, W.K. Dickson, D.A. Smith, R.F. Bara, M. Mohr, and E. Watkins. 2003. Performance of fine fescue cultivars and selections in New Jersey turf trials. Rutgers Turfgrass Proc. 34:27-56.

Han, Y., P. Perdomo, J.A. Murphy, W.A. Meyer, S.A. Bonos, W.K. Dickson, D.A. Smith, R.F. Bara, M.M. Mohr, and E. Watkins. 2002. Performance of fine fescue cultivars and selections in New Jersey turf trials. Rutgers Turfgrass Proc. 33:23-52.

Howard, H.F. and T.L. Watschke. 1991. Variable high-temperature tolerance among kentucky bluegrass cultivars. Agron. J. 83:689-693.

Huang, B., J.D. Fry, and B. Wang. 1998. Water relations and canopy characteristics of tall fescue cultivars during and after drought stress. HortScience 35:837-840.

Huang, B. and J. Fu. 2001. Growth and physiological responses of tall fescue to surface soil drying. Intl. Turfgrass Soc. Res. J. 9:291-296.

Huang, B. and H. Gao. 1999. Physiological responses of diverse tall fescue cultivars to drought stress. HortScience 34:897-901.

Jiang, Y. and B. Huang. 2000. Effects of drought or heat stress alone and in combination on kentucky bluegrass. Crop Sci. 40:1358-1362.

Jiang, Y. and B. Huang. 2001. Physiological responses to heat stress alone or in combination with drought: A comparison between tall fescue and perennial ryegrass. HortScience 36:682-686.

Liu, X. and B. Huang. 2000. Heat stress injury in relation to membrane lipid peroxidation in creeping bentgrass. Crop Sci. 40:503-510.

Minner, D.D., P.H. Dernoeden, D.J. Wehner, and M.S. McIntosh. 1983. Heat tolerance screening of field-grown cultivars of kentucky bluegrass and perennial ryegrass. Agron. J. 75:772-775.

Morris, K.N. 2002. National fineleaf fescue test-1998. Progress report. NTEP no. 03-6. National Turfgrass Evaluation Program, U.S. Dept. Agr., Agr. Res. Serv., Beltsville, Md.

Park, S.Y., K.C. Chang, R. Shivaji, and D.S. Luthe. 1997. Recovery from heat shock in heat-tolerant and nontolerant variants of creeping bentgrass. Plant Physiol. 115:229-240.

Qian, Y.L., J.D. Fry, and W.S. Upham. 1997. Rooting and drought avoidance of warm-season turfgrasses and tall fescue in Kansas. Crop Sci. 37:905-910.

Salaiz, T.A., R.C. Shearman, T.P. Riordan, and E.J. Kinbacher. 1991. Creeping bentgrass cultivar water use and rooting responses. Crop Sci. 31:1331-1334.

Steiner, J.J., T.G. Brewer, and S.M. Griffith. 2001. Temperature effects on interspecific interference among two native wetland grasses and tall fescue. Agron. J. 93:1020-1027.

Watkins, E. and W.A. Meyer. 2005. Evaluation of tufted hairgrass germplasm as low-maintenance turf. Intl. Turfgrass Soc. Res. J. 10:666-673.

Wehner, D.J. and T.L. Watschke. 1981. Heat tolerance of kentucky bluegrasses, perennial ryegrasses, and annual bluegrass. Agron. J. 73:79-84.

$\mathrm{Xu}, \mathrm{Q}$. and B. Huang. 2001a. Lowering soil temperatures improves bentgrass growth under heat stress. Crop Sci. 41:1878-1883.

$\mathrm{Xu}, \mathrm{Q}$. and B. Huang. 2001b. Morphological and physiological characteristics associated with heat tolerance in creeping bentgrass. Crop Sci. 41:127-133. 